\title{
Early response in pandemics: importance and challenges in Sri Lanka
}

Withanage Iresha Udayangani Jayawickrama ${ }^{1^{*}}$, Pasyodun Koralage Buddhika Mahesh ${ }^{2}$, Sameera Jayan Senanayake, Charith Amidha Hettiarachchi ${ }^{4}$, Yasaswi N Walpita ${ }^{5}$, Sathira Perera ${ }^{6}$, Shilanthi Senewiratne $^{2}$, Udari Mambulage ${ }^{5}$, Dimuth Peiris ${ }^{7}$, Nalin Ariyarathne, Amila Chandrasiri ${ }^{2}$, Nelum Samaruthilaka' ${ }^{9}$ Upuli Perera $^{3}$, SM Arnold $^{10}$, Ruwan Ferdinando ${ }^{10}$

${ }^{1}$ University of Lincoln, UK; ${ }^{2}$ University of Melbourne, Australia; ${ }^{3}$ Queensland University of Technology, Australia; ${ }^{4}$ University of Technology Sydney, Australia; ${ }^{5}$ Cardiff University, UK; ${ }^{6}$ University of New South Wales, Australia; ${ }^{7}$ University of Keele, UK; ${ }^{8}$ University of Warwick, UK; ${ }^{9}$ University of Cambridge, UK; ${ }^{10}$ Ministry of Health, Sri Lanka

"Correspondence: dr.iresha@yahoo.com https://orcid.org/0000-0003-4213-3728

DOI: https://doi.org/10.4038/jccpsl.v26i5.8318

Received on 7 May 2020

Accepted on 23 May 2020

\section{Summary}

The world is facing an unexpected challenge of a newly emergent pandemic, COVID-19. It has led to unprecedented impacts on public health and economy. As of 27 May 2020, there have been 5,593,148 cases of COVID-19 worldwide, with 350,509 deaths. In the absence of a disease specific therapeutics or vaccine for this novel virus, different combinations of non-pharmaceutical interventions have been employed to interrupt the transmission and contain the outbreak globally. However, logistical, human resource and economyrelated factors make the battle against Covid-19 more challenging in both developing and developed countries. This narrative report highlights the early response and its impact in controlling COVID-19 and challenges faced by the healthcare system in Sri Lanka.

\section{Public health response and its impact}

Importance of an early response in combating COVID-19

The mean incubation period of COVID-19 is around 5-6 days, though it can take up to 14 days (1). During this period, some infected cases can be contagious with no related symptoms. The novel virus is highly transmissible with an average basic reproduction number (R0) of 2.2 (2), depicting that one infected person would transmit the virus to 2.2 secondary persons in a completely susceptible population. COVID-19 has shown a wide spectrum of disease severity ranging from, asymptomatic to critically ill (3), and has a fatality rate of around $2.3 \%$ (4). Due to these reasons, controlling the spread of COVID-19 becomes challenging.

In the absence of a disease-specific therapeutics or vaccine for the novel virus, different combinations of non-pharmaceutical interventions have been 
employed to interrupt the transmission and contain the outbreak. The combination of these interventions can elicit two main strategies in the control of COVID-19, namely 'mitigation' and 'suppression' (5). The strategies differ in whether they aim to reduce the basic reproduction number to below 1 (i.e. suppression) and thereby cause case numbers to decline or to merely slow the spread by reducing R0 but not below 1 (i.e. mitigation). In mitigation, population immunity builds up through the epidemic leading to an eventual rapid decline in case numbers and transmission dropping to low levels. Optimal mitigation policies might reduce peak healthcare demand by $2 / 3^{\text {rd }}$ and deaths by half. Suppression aims to reverse the epidemic growth and thereby reduce case numbers. The main challenge of this approach is that non-pharmaceutical interventions need to be maintained, at least intermittently, as long as the virus is circulating in the human population or until a vaccine becomes available. When all these factors are concerned, an early response becomes a critical factor in combating COVID-19.

\section{Challenges of responding to COVID-19 in resource-constrained settings}

Fighting against COVID-19 was identified as one of the greatest challenges to humans in recent history (6). The disease has not displayed any discrimination over countries challenging their health systems invariably (7). Globally, the recommendation of managing severe and critical patients is admission to a hospital, while mild-to-moderate cases should be managed considering other clinical and risk factors (7). This reflects that if the case numbers rise, resources at the curative settings must be available to prevent mortality.

The clinical guidelines for management of COVID19 in Sri Lanka advocates hospital admission of all suspected and confirmed cases (8-9). Therefore, the parameters such as hospital bed strength, critical care bed availability, human resources and investigation facilities play a critical role in the success of clinical management (10). Therefore, the curative management of COVID-19 cases can be a significant burden to a developing country like Sri Lanka.
The Sri Lankan intensive care unit (ICU) beds are about 2.59 per 100,000 population, which is about 500 ICU beds (11). Assuming that $5 \%$ of the patients need ICU admission and about 200 ICU beds are utilized for other critical illnesses, Sri Lankan ICU beds would get saturated if the country gets around 6000 active COVID-19 cases, though emphasis is currently on enhancing the ICU capacities to cater to the increased demand in future. Even the countries with better bed strength and critical care facilities are facing major difficulties with a higher number of COVID-19 cases. Italy and the United States are such examples (12-13). Therefore, to prevent the collapse of the healthcare system, the number of COVID-19 cases admitted to hospitals must be kept below the threshold (14). This is further complemented by the financial burden associated with investigations and logistical requirements of quarantine services. On the other, utilization of the public health staff solely for COVID-19 services would disrupt the other essential routine public health services. Besides, the healthcare system is challenged by increasing numbers of infected healthcare workers during the pandemic. Nearly $20 \%$ of the healthcare workers in Italy and about 3300 health workers in China are infected (15). As the pandemic spreads, the shortage of personal protective equipment has become a major concern (16). Moreover, the stringent measures which are currently in place to contain the spread of the disease have triggered economic fallout globally. It is challenging to a resource-constrained country like Sri Lanka to continue the lockdown due to economic instability. All these logistical, human resource and economy-related factors make the battle against COVID-19 more challenging in Sri Lanka.

\section{Sri Lankan response and its impact compared to other countries}

Since there is no universal agreement or recommendation on the best strategy to be implemented, countries have committed to different strategies. Similarly, there is no global consensus on the promptness of a country's responses related to each strategy, albeit in general, the countries with early response have achieved flattening of the curve leading to a lower burden compared to those with a late response (Figure 1) (17). 


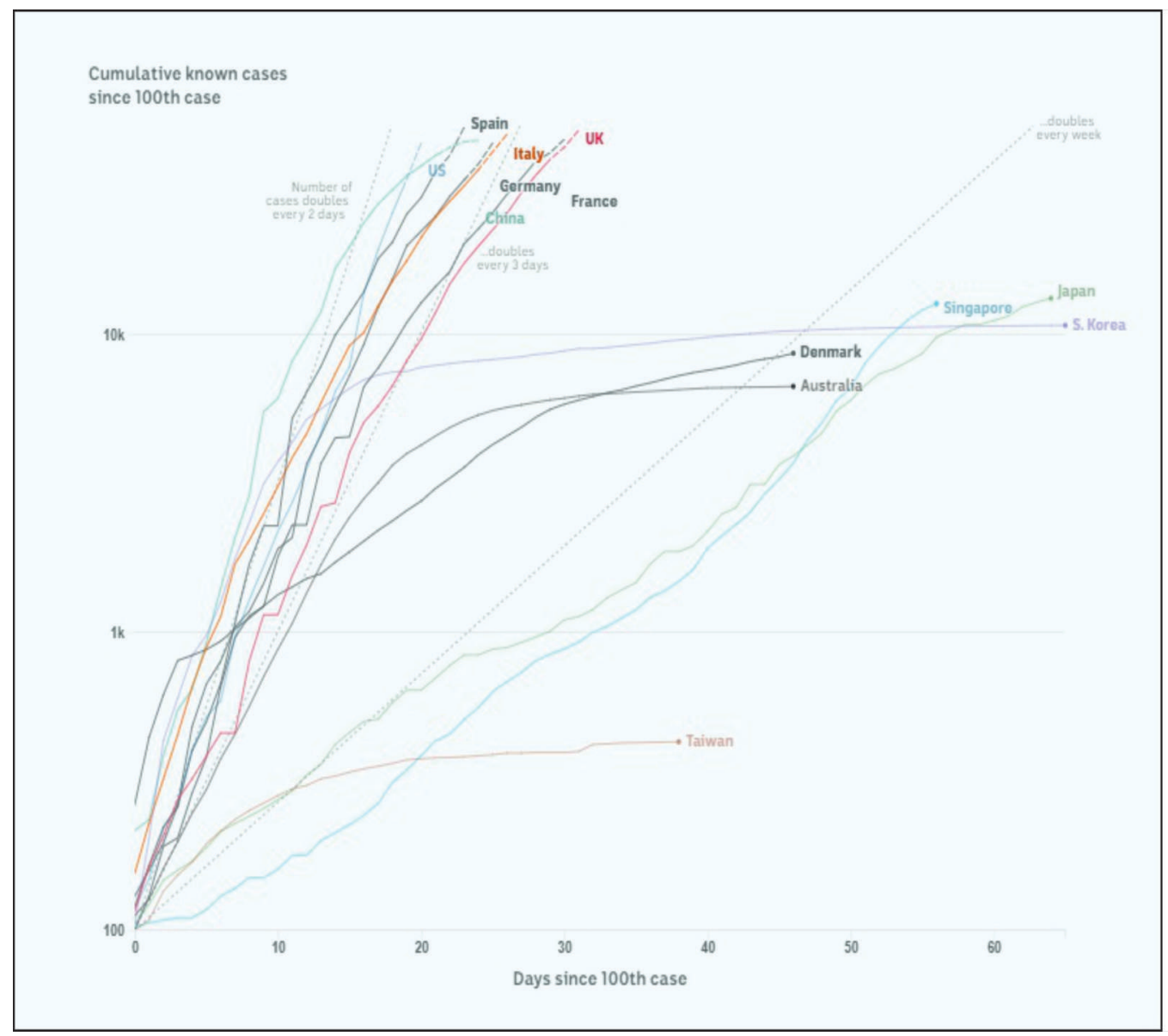

Figure 1: Distribution of the caseload after 100 cases of selected countries (17)

Taiwan, Japan, South Korea and Singapore are the few countries that demonstrated an 'early' response. Russia, Denmark and Australia are countries that committed a response that is debatable whether early or comparatively late. Hence, they were classified as having an 'intermediate' response. Arguably Italy, United States and Spain can be mentioned as countries that committed a 'delayed' response leading to a drastic rise in the number of cases.

Sri Lanka reported the first confirmed local case of COVID-19 on 11 March 2020. In response, Sri Lanka executed an array of control measures immediately (18). As an early response, the National Corona Task Force was established on 26 January 2020 with multistakeholder participation. At entry points, thermal scanning of all the passengers was initiated and a health declaration form was introduced to facilitate the screening and follow up of any suspected case.
All the returnees from the countries with ongoing outbreaks were quarantined for fourteen days starting from 10 March. All the schools were closed by 13 March. It was complemented by the suspension of the inbound flights on 19 March. Therefore, Sri Lanka's response can be classified as relatively prompt in relation to many other countries (19-22).

The Government of Sri Lanka imposed lockdown styled curfew in Puttalam, Negombo, Kochchikade and Chilaw on 19 March 2020, which was extended to the entire country (23). Since then, there had been customization of lockdown in a few selected parts of the country (24-25). Further, the Minister of Health gazetted new regulations under Quarantine and Prevention of Diseases Ordinance to strengthen the combat against COVID-19. Medical officers of health $(\mathrm{MOH})$ and Additional $\mathrm{MOH}$ were appointed as 'proper authorities'. COVID-19 was named as a quarantinable disease (26). 


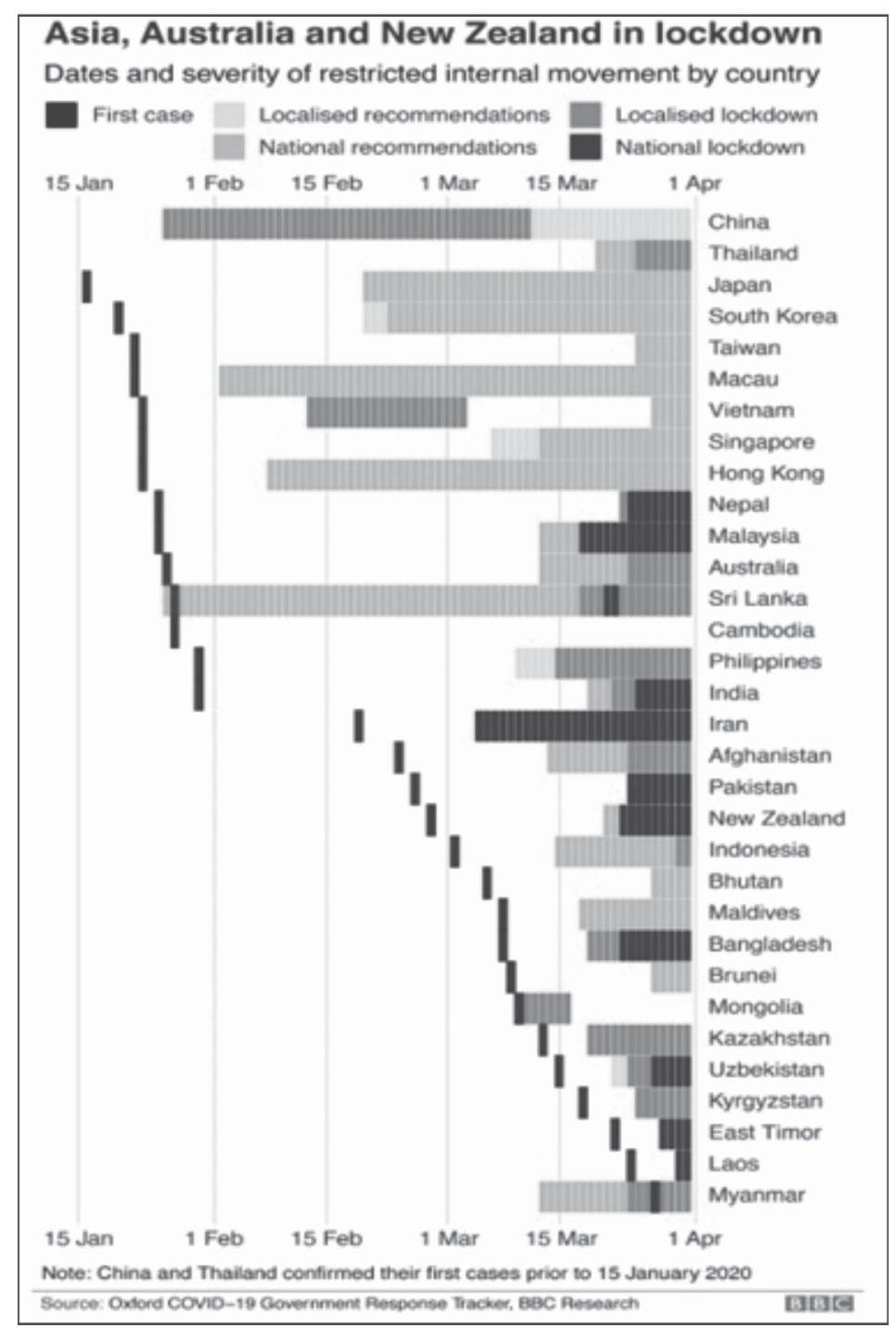

Figure 2: Promptness of the response of Asia, Australia and New Zealand (27)

According to Figure 2, Sri Lanka is among the few countries that successfully implemented national level recommendations and lockdown at an earlier stage. This further complements the fact that the country's response has been prompt.

Another distinctive feature of Sri Lankan response is the prompt utilization of the well-established public health infrastructure (28-29). The $\mathrm{MOH}$ units got actively engaged in monitoring and contact tracing (28). Similarly, Sri Lanka practised a unique approach to contain the spread by tracing the contacts with the help of tri-forces, police and intelligence services. The current approach in relation to public health, which is strengthened by the role of consultant community physicians (CCPs), enabled this dynamic island-wide response.

\section{Implications and recommendations}

Sri Lankan response has managed to maintain the number of cases below the saturation level despite hospitalizing all positive cases including the asymptomatic cases. Out of the positive cases, $40 \%$ are asymptomatic (30) and this justifies how aggressive Sri Lanka's mitigation efforts were. This was contributed by the well-established public health infrastructure, prompt response and dedication of staff members of both preventive and curative sectors.

Sri Lanka's COVID-19 response suggests that even resource-constrained settings can face the challenges of pandemics with prompt response. The presence of a well-established public health infrastructure was 
invariably an additional advantage in this process. The way forward for Sri Lanka must include a comprehensive post-COVID-19 evaluation and preparation for a subsequent pandemic. Potential opportunities for intervening would include strengthening the curative sector service delivery with that of the preventive sector. Revisiting the priorities for positioning of CCPs in this regard seems timely. This must be complemented by the necessary post-graduate curriculum revisions and other structural modifications to the health system.

\section{Author Declaration}

Author contributions: All authors were involved in planning of the article and in literature search. WIUJ drafted the manuscript and all authors were involved in editing it. SMA and RF did the overall supervision. All authors approved the final manuscript.

\section{References}

1. WHO. Novel Coronavirus (2019-nCoV): Situation Report-3, 23 January 2020. Geneva: World Health Organization, 2020. Available from: https:// www.who.int/ docs/default-source/corona viruse/situation-reports/ 20200402-sitrep-73covid-19.pdf? sfvrsn= 5ae25bc7_6. Accessed 2 May 2020.

2. Li Q, Guan X, Wu P, Wang X, Zhou L, Tong Y, et al. Early Transmission dynamics in Wuhan, China, of the novel coronavirus infected pneumonia. New England Journal of Medicine 2020; 382(13): 11991207. DOI: 10.1056/NEJMoa2001316.

3. Hens N, Vranck P, Molenberghs G. The COVID19 epidemic, its mortality, and the role of nonpharmaceutical interventions. European Heart Journal: Acute Cardiovascular Care 2020; 9(3): 204-208. DOI: 10.1177/2048872620924922.

4. Ruan S. Likelihood of survival of coronavirus disease 2019. The Lancet Infectious Diseases 2020; 20(6): 630-631. DOI: 10.1016/S14733099(20) 30257-7.

5. Ferguson NM, Laydon D, Nedjati-Gilani G, Imai $\mathrm{N}$, Ainslie K, Baguelin M, et al. Impact of nonpharmaceutical interventions (NPIs) to reduce COVID-19 mortality and healthcare demand. Imperial College COVID-19 Report Series, 16
March 2020. Available from: https://doi.org/10. $25561 / 77482$.

6. Qian X, Ren R, Wang Y. Fighting against the common enemy of COVID-19: a practice of building a community with a shared future for mankind. Infectious Diseases of Poverty 2020; 9: 34. DOI: 10. 1186/s40249-020-00650-1.

7. Centres for Disease Control and Prevention. COVID-19 - Clinical care. Centers for Disease Control and Prevention, 2020. Available from: https://www.cdc.gov/coronavirus/2019-ncov/hcp /clinical-guidance-management-patients.html. Accessed 2 May 2020.

8. Epidemiology Unit. Provisional Clinical Practice Guidelines on COVID-19 Suspected and Confirmed Patients. Ministry of Health, Nutrition and Indigenous Medicine, Sri Lanka, 2020. Available from: https://www.epid.gov.lk /web/images/pdf/ Circulars/Corona_virus/covid19\%20cpg \%20_\%20version\%204.pdf. Accessed 1 May 2020.

9. Epidemiology Unit. Updated interim case definition and advice on initial management. Ministry of Health, Nutrition and Indigenous Medicine, Sri Lanka, 2020. Available from: https://www. epid.gov. lk/web/images/pdf/ Circulars /Corona_ virus/revisionsummary.pdf. Accessed 1 May 2020.

10. European Centre for Disease Prevention and Control. Coronavirus disease 2019 (COVID-19) pandemic: increased transmission in the EU/EEA and the $U K-7^{\text {th }}$ update UK 2020. Available from: https://www.ecdc.europa .eu/sites/ default/files/ documents/RRA-Seventh-Update-Outbreak.

11. Pieris L, Sigera PC, De Silva AP, et al. Experiences of ICU survivors in a low middle-income countrya multi-center study. BMC Anesthesiology 2018; 18(1): 30. DOI: 10.1186/s12871-018-0494-8.

12. Rhodes A, Ferdinande P, Flaatten H. et al. The variability of critical care bed numbers in Europe. Intensive Care Medicine 2012; 38: 1647-1653. DOI: 10.1007/s00134-012-2627-8.

13. Wallace DJ, Angus DC, Seymour CW, Barnato AE, Kahn JM. Critical care bed growth in the United States. A comparison of regional and national trends. American Journal of Respiratory Critical Care Medicine 2015; 191(4): 410-416. DOI: 10.1164/rccm.201409-1746OC. 
14. Joseph T Wu, Kathy Leung, Mary Bushman. et al. Estimating clinical severity of COVID-19 from the transmission dynamics in Wuhan, China. Nature Medicine 2020; 26: 506-510. DOI: 10.21203/ rs.3.rs-17453/v1.

15. The Lancet. COVID-19: protecting health-care workers. The Lancet 2020; 395(10228): 922. DOI: 10.1016/S0140-6736(20)30644-9.

16. Sudip B, Md Mahbub H, Amarjeet S. Addressing the shortage of personal protective equipment during the COVID-19 pandemic in India-a public health perspective. AIMS Public Health 2020; 7(2): 223-227. DOI: 10.3934/publichealth .2020019.

17. ABC News. What we can learn from the countries winning the coronavirus fight, 2020. Available from: https://www.abc.net. au/news/2020-03-26/ coronavirus-covid19-global-spread-dataexplained/ 12089028 . Accessed 2 May 2020.

18. The College of Community Physicians of Sri Lanka. Flattening the epidemic curve of COVID19 in Sri Lanka: The Public Health Response - A communique from the College of Community Physicians of Sri Lanka, 2020. Journal of the College of Community Physicians of Sri Lanka 2020; 26(1): 56-64. DOI: 10.4038/jccpsl.v 26i1.8311.

19. Foreign Policy. The countries that are succeeding at flattening the curve 2020. Available from: https://foreignpolicy.com /2020/04/02/countriessucceeding-flattening-curve-coronavirus-testingquarantine/. Accessed 2 May 2020.

20. Foreign Policy. Fear of China made Taiwan a coronavirus success story in 2020. Available from: https://foreignpolicy.com /2020/03/16/ taiwanchina-fear-corona virus-success/. Accessed 2 May 2020 .

21. Foreign Policy. Sweden is open for business during its coronavirus outbreak 2020. Available from: https://foreignpolicy.com /2020/03/24/swedencoronavirus-open-for-business/. Accessed 2 May 2020 .

22. Foreign Policy. In the coronavirus, Putin may have met his match 2020. Available from: https:// foreignpolicy.com /2020/03/30/ coronavirus- putin-met-his-match-covid/. Accessed 1 May 2020.

23. Economy Next. Sri Lanka in lockdown-style coronavirus curfew as count moves up, markets wobble. 2020. Economy Next. Available from: https://economynext.com/ sri-lanka-in-lockdownstyle-coronavirus-curfew-as-count-moves-upmarkets-wobble-60503/. Accessed 2 May 2020.

24. Aljazeera. Sri Lanka extends nationwide curfew to fight coronavirus pandemic.2020. Aljazeera. Available from: https://www. aljazeera.com/news/ 2020/03/coronavirus-pandemic-sri-lankaextends-curfew-worst-hit-areas-20032311360 1372. html . Accessed 2 May 2020.

25. News First. Curfew in Ratnapura, Pelmadulla police divisions until further notice.2020. Sirasa Television, 2 May 2020. Available from: https://www.newsfirst.lk/ 2020/04/09/curfew-inratnapura-pelma dulla-police-divisions-untilfurther-notice/

26. Government Publication Bureau. Quarantine Regulations 2020. Available from: https:// www.dgi. gov.lk/. Accessed 5 May 2020.

27. BBC News. Coronavirus: the world in lockdown in maps and charts 2020. Available from: https:// www.bbc.com/news/amp/world-52103747.

28. Senanayake S, Senanayake B, Ranasinghe T, Hewageegana NSR. How to strengthen primary health care services in Sri Lanka to meet the future challenges. Journal of the College of Community Physicians of Sri Lanka 2017; 23(1): 43-49. DOI: 10.4038 /jccpsl.v23i1.8.

29. Mahesh PKB, Gunathunga MW, Arnold SM, de Silva LD, Wijeratne MP, Weragoda. Will prevention be better than cure? The challenge of retaining health staff in the public health sector in Sri Lanka. Journal of the College of Community Physicians of Sri Lanka 2018; 24(1): 36-38. DOI: 10.4038/jccpsl.v24i1.8143.

30. Sri Lanka Medical Association. Institutional Preparedness and response for COVID-19 outbreak. Available from: https://www. youtube. $\mathrm{com} /$ watch? $\mathrm{v}=$ YxLpKuoRxeY\&feature=you tube .Accessed on 6 May 2020. 